\title{
GROWING APART? A TALE OF TwO REPUBLICS: ESTONIA AND GEORGIA
}

\author{
THORVALDUR GYLFASON \\ EDUARD HOCHREITER
}

CESIFO WORKING PAPER NO. 2155

CATEgORY 5: Fiscal POLICY, MACROECONOMICS AND GROWTH

DECEMBER 2007

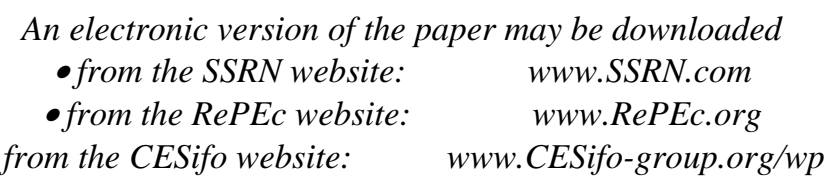




\title{
GROWING APART? A TALE OF TWO REPUBLICS: ESTONIA AND GEORGIA
}

\begin{abstract}
We compare and contrast the economic growth performance of Estonia and Georgia since the collapse of the Soviet Union in 1991 in an attempt to understand better the extent to which the growth differential between the two countries can be traced to increased efficiency in the use of capital and other resources (intensive growth) as opposed to brute accumulation of capital (extensive growth). We infer that advances in education at all levels, good governance, and institutional reforms have played a more significant role in raising economic output and efficiency in Estonia than in Georgia which remains marred by various problems related to weak governance in the public and private spheres.
\end{abstract}

JEL Code: 016.

Keywords: economic growth, governance, transition economies.

\author{
Thorvaldur Gylfason \\ University of Iceland \\ 101 Reykjavík \\ Iceland \\ gylfason@hi.is
}

\author{
Eduard Hochreiter \\ Joint Vienna Institute \\ Mariahilfer Str. 97 \\ 1060 Vienna \\ Austria \\ ehochreiter@jvi.org
}

November 2007

We would like to thank Nikoloz Gigineishvili, Ekke Nõmm, Martti Randveer, and Märten Ross for their detailed comments on an earlier version of the paper. The views expressed in the paper should not be attributed to the institutions with which we are affiliated. 


\section{Introduction}

Looking at the fate of the fifteen states that emerged from the Soviet Union, we find it striking how different their economic evolution has been since the collapse of the Soviet Union in 1991. One especially interesting feature is that the three Baltic States that are now members of the European Union (EU) have fared so much better in economic terms than any of the other Former Soviet Union (FSU) states, including Russia (Figure 1). The question is: Why?

This paper aims to shed light on this question by applying standard growth economics to a comparison of the recent growth performance of two of the FSU countries, Estonia and Georgia, one from each tier in Figure 1. Both countries are small (45,226 km², population 1.3 million, and 69,700 km², population 4.7 million, respectively). Both are poorly endowed with natural resources, which may be good for their growth potential as suggested by Sachs and Warner (1995) and others, and both share a distant history of prosperity which, at the time, brought them considerable wealth. Estonia prospered when Tallinn (Reval) became part of the Hanseatic League, from 1285 onward. Georgia also prospered it its Golden Era from the $11^{\text {th }}$ to the $13^{\text {th }}$ century when the Georgian kingdom expanded to include most of the Caucasus before disintegrating in the $15^{\text {th }}$ century following the Mongol invasions. Imperial Russia illegally annexed Georgia in 1801. Estonia's fortune did not last either. Having first been brought under Swedish rule in the turbulent $16^{\text {th }}$ and $17^{\text {th }}$ centuries (southern Estonia briefly also came under Polish-Lithuanian rule), Estonia, like Georgia 80 years later, was annexed by Russia in 1721.

Both countries became independent in 1918. Estonia retained its independence until 1940, when it was annexed by the Soviet Union under the Hitler-Stalin Pact. At the time, Estonia's national income per capita was roughly on par with that of Finland across the bay. Georgia's independence was much more short-lived, because the Red Army invaded the country in 1921 on the orders of Joseph Stalin, a native Georgian (and, incidentally, against the wishes of Lenin). The reversal of fortune experienced by both countries accords with the view advanced particularly clearly by Acemoglu, Johnson, and Robinson (2002) that institutions - in the present case, bad institutions matter for economic growth. Geography isn’t everything.

Under Soviet rule, the economic decline of the three Baltic republics - Estonia, Latvia, and Lithuania - was substantial but, overall, their economic situation remained 
better than in other Soviet republics, not least the Caucasus republics. However, official statistics may have overstated the differences because of Georgia's larger underground - that is, unrecorded - economy. In any case, the initial conditions for economic catch-up following Estonia and Georgia's secession from the Soviet Union in 1991 were more favorable in Estonia than in Georgia. Even so, Estonia's gross domestic product (GDP) per capita adjusted for purchasing power parity had sunk from approximate parity in 1940 to about one third of that of Finland in 1991. Estonia, after regaining independence in 1991, quickly embarked on bold and decisive political, institutional, and economic reforms that were carried out by successive coalition governments from different parts of the political spectrum. Within less than fifteen years, Estonia was able to accede to the EU and its gross national income (GNI) per capita rose to a half of that of Finland. Today, Estonia is on a strong, sustainable path of rapid real growth and convergence to Finland and the rest of the EU membership. Moreover, apart from its inflation rate that, according to the Maastricht criteria, remains too high, Estonia is ready to adopt the euro and discard the kroon.

In contrast, Georgia, after regaining independence, was torn by civil war, was caught in a low-income trap, and suffered from pervasive corruption as well as from a conspicuous lack of economic and institutional reforms. It was not until the Rose Revolution in 2003, which led to the fall of the Shevardnadze government, that the situation of the country changed enough to rekindle hopes for fundamental political, institutional, and economic reforms that could at last make economic catch-up feasible. In 2007, Georgia became "the number one economic reformer” according to World Bank (2007). Between 2006 and 2007 Georgia skyrocketed from $112^{\text {th }}$ place to $18^{\text {th }}$ by the World Bank's Ease of Doing Business Index where Georgia is now just one place behind Estonia, which ranks $17^{\text {th }}$ (same source).

The national economy of the Soviet Union and its constituent republics is now widely acknowledged to have been stagnant or worse for quite some time before the economic collapse that commenced in 1989. The severity of the plunge during and after 1989 varied from republic to republic and was probably closely related to the extent of the systemic failure of central planning as well as to local mismanagement that preceded the plunge. As Figure 2 shows, the plunge was significantly deeper and lasted longer in Georgia than in Estonia. In Georgia, GDP per capita measured in constant US dollars at 2000 prices and adjusted for purchasing power parity 
contracted by almost 80 percent from 1988 to 1994 while in Estonia the contraction amounted to 33 percent from 1989 to 1993. Even so, since 1993, Estonia’s GDP per capita has subsequently grown more rapidly than that of Georgia, or by 6.6 percent per year compared with 6.1 percent in Georgia.

Estonia's more rapid growth after the initial plunge may seem surprising because it might have appeared easier for Georgia to grow more rapidly from such a low initial level of output after the fall. The fact that Estonia grew more rapidly than Georgia after the collapse suggests that initial output was only one of several determinants of the two countries' growth trajectories during this period. In 1980, Estonia's GDP per head was about 1.5 times that of Georgia. Since 1993, the income differential between the two countries has exceeded four, approaching five. A logarithmic representation of the evolution of GDP per capita in Figure 3 suggests that the income differential between the two countries in 2005, the latest year for which comparable GDP figures are available from the World Bank’s World Development Indicators 2007 at the time of writing, stems mostly from the fact that, of the two, Georgia suffered a much deeper contraction of measured output after 1989. The puzzle here is: Why, then, did Georgia not grow more rapidly than Estonia thereafter?

To repeat, Estonia has had a double advantage over Georgia. Estonia grew much more rapidly from 1991 to 2006 both because the initial slump of output was shallower and more short-lived than in Georgia and also because, after the slump, Estonia managed to grow more rapidly than Georgia despite Georgia's much lower initial level of output per person when growth resumed in 1994.

The remainder of the paper is organized as follows: Section 2 lays out, in the simplest possible terms, the theoretical framework guiding the discussion to follow. In Section 3, selected economic, political, and social indicators are employed to illuminate the possible reasons for the divergent economic developments in the two countries under review. In Section 4, before summarizing our main findings, we briefly discuss the policy implications of the growth experiences of the two countries and suggest potential lessons for other countries that lag behind their erstwhile equals.

\section{Theoretical Background}

Economic growth can be either extensive, driven forward by the accumulation of dead capital, or it can be intensive, by which is meant growth that springs from more 
efficient use of existing capital and other resources. Among the numerous alternative ways of increasing economic and social efficiency, one of the most obvious is the accumulation of live capital - that is, human capital - through education, on-the-job training, and health care. There are many other ways as well to increase efficiency and thereby economic growth. Adam Smith and David Ricardo showed how free trade can enable individuals and countries to break outside the production frontiers that, under autarky, would confine them to lower standards of life. Other examples abound, as the theory of endogenous economic growth and its empirical implementation in recent years have made clear. Today, for instance, in view of the rapidly advancing theoretical and empirical literature on economic growth, it is now widely recognized that the quality of institutions and good governance can help generate sustained economic growth and so can also various other factors that are closely related to economic organization, institutions, and policy (Acemoglu and Johnson, 2005; see also Dixit, 2004). We want to ascertain whether the growth differential between Estonia and Georgia since 1991 can be traced mostly to efficiency (i.e., intensive growth), as we suspect, rather than accumulation (i.e., extensive growth).

To set the stage, consider the constant-returns-to-scale production function:

$$
Y=A H^{a} K^{b} N^{c} L^{1-a-b-c}
$$

Here $\mathrm{Y}$ is national economic output, $\mathrm{A}$ is a parameter that reflects total factor productivity (TFP), or efficiency, that is, the ability to convert inputs into output, $\mathrm{H}$ is human capital, $\mathrm{K}$ is real capital, $\mathrm{N}$ is natural capital, including land, and $\mathrm{L}$ is raw labor. The four exponents are the output elasticities of the inputs and lie between zero and one. By dividing through the production function by labor, we obtain this standard expression for output per person:

$$
\frac{Y}{L}=A\left(\frac{H}{L}\right)^{a}\left(\frac{K}{L}\right)^{b}\left(\frac{N}{L}\right)^{c}
$$

Hence, output per capita depends on four factors:

(i) Efficiency

(ii) Human capital per person

(iii) Capital/labor ratio

(iv) Natural capital per person 
There are two things to note about this classification. First, if it so happened that human capital, real capital, and natural capital all grew at the same rate as the labor force, then advances in efficiency (A) would remain as the sole source of economic growth, by which we mean the rate of growth of output per person. The second point is that just as, in nature, some plants grow faster than others, so do different types of capital grow at different rates. While experience suggests that real capital grows at roughly the same rate as output over long periods, rendering the capital/output ratio constant over time, human capital can easily grow more rapidly than real capital, while natural capital - certainly that part of it that is nonrenewable, but also some renewable natural capital such as fish in the sea - tends to grow less rapidly than real capital. This, by the way - or think of fixed land, if you prefer - is why increased population growth, against common intuition, tends to slow down economic growth.

Different growth rates of the different determinants of economic growth mean that the rate of growth of output per capita must be a weighted combination of the growth rates of the different inputs. We could simplify the story by imposing on the production function the requirement that capital and output grow in tandem. If we did, as is customary in parts of the growth literature, this would reduce the number of the determinants of long-run growth from four to three: efficiency, human capital per person, and natural capital per person. We do not, however, pursue this simplification here because we want to emphasize not so much long-run growth of potential output as the medium-term growth of the actual level of output. In our equations above, the efficiency parameter A comprises a variety of factors, among them technological advances and other types of efficiency gains from various sources, including internal as well as external trade, "good” institutions, and "good” governance (Williamson, 2005; see also Marsiliani and Renström, 2007). Governance, in turn, is a broad concept, and subsumes managerial, fiscal, monetary, financial, and external governance, each of which comprises several components.

The examination of some of these "unbundled" governance factors is at the core of our attempt to answer the question of why Estonia has grown so much more rapidly than Georgia. This requires a comparative review of a number of different economic, political, and social indicators to which we now turn. 


\section{Empirical Evidence}

We are aware that fifteen years of macroeconomic data following the collapse of the Soviet Union that started in 1989 is too short a period to be amenable to a fully fledged long-run economic growth analysis in the spirit of, for example, Hall and Jones (1999). Instead, against the background provided in the preceding section, we intend to ask whether the pattern of those macroeconomic variables that recent growth research has identified as potentially important determinants of output per person and thereby also ultimately of long-run economic growth in cross-country comparisons have behaved in ways that can shed some light on economic developments in Estonia and Georgia since independence. Full-fledged growth accounting in which output growth could be traced in quantifiable proportions to the underlying inputs and the efficiency with which they were used is beyond the scope of the present exercise.

\section{A. Investment and Education}

Let us start with domestic investment, a key determinant of the capital/labor ratio and of economic growth. Which of the two countries has put aside more resources for capital formation since 1989? As Figure 4 shows, Estonia invested 29 percent of GDP in machinery and equipment on average from 1989 to 2005 compared with 20 percent in Georgia. The same applies to investments in human capital. With 95 percent enrolment at the primary-school level, Georgia has not quite achieved parity with Estonia's 100 percent primary-school enrolment rate. Moreover, Figure 5 shows that nearly all Estonian youngsters attend secondary schools compared with four fifths of Georgians. In 2004, nearly two thirds of young Estonians attended colleges and universities compared with 42 percent in Georgia. In recent years, public and private expenditure on education amounted to about six percent of GDP in Estonia compared with two percent in Georgia.

Other indicators point in the same direction. In Estonia, there were 483 personal computers per 1,000 inhabitants in 2005, almost the same figure as in Finland, compared with 42 personal computers in Georgia in 2004. Likewise, in Estonia, there were 513 internet users per 1,000 inhabitants in 2005, the same as in Finland in 2004; the Georgian figure for 2004 is 39 internet users per 1,000 inhabitants. Estonia now has more mobile phone subscribers than people, surpassing even Finland next door, while Georgia has 326 mobile phone subscribers per 1,000 inhabitants. Education and 
technological sophistication are clearly conducive to a business-friendly climate for domestic as well as foreign investment.

Understandably, foreign investment was virtually nonexistent in the early 1990s, but since then Estonia has attracted more capital from abroad than Georgia. Specifically, net inflows of foreign direct investment in Estonia amounted to seven percent of GDP 1992-2005 on average compared with four percent in Georgia (Figure 6). Estonia has clearly been more open toward the influx of foreign capital.

Domestic and foreign investment and education at all levels are key sources of the accumulation of real capital and human capital. Together as well as separately, they are important determinants of output per person and economic growth. As far as those two time-honored pillars of productivity and growth are concerned, Estonia outperformed Georgia during the transition period, so there is perhaps little wonder, then, that Estonia's output per person has grown more rapidly than that of Georgia. Today, the people of Estonia enjoy a markedly higher standard of life than they did under Soviet rule whereas the people of Georgia remain significantly worse off (recall Figures 1 and 2).

\section{B. Exports, Inflation, and Economic Structure}

Estonia has also been more open than Georgia toward foreign trade. Exports of goods and services from Estonia were equivalent to 73 percent of GDP on average 19922005 compared with 33 percent in Georgia (Figure 7). The export figures include reexports. While Estonia eliminated all import duties after 1995, Georgia has continued to depend on such import restrictions for about ten percent of its tax revenues (Figure 8). Further, it takes, on average, twice as long for importers to clear customs in Georgia (3.4 days) as in Estonia (1.7 days). Free trade is good for growth.

Price stability is also good for growth. Figure 9 shows that in the 1990s Georgia managed to bring inflation down almost as far as Estonia. However, in the early 1990s inflation was much higher in Georgia than in Estonia as a result of severe initial monetary overhang and other problems. It is, therefore, not surprising that the process of monetization of economic transactions has been slower in Georgia than in Estonia (Figure 10). Most African countries have a higher ratio of broad money to GDP - that is, greater financial depth - than Georgia. High inflation tends to hold back economic growth through various channels. It tends to do so by reducing financial depth, among 
other things, or, if you prefer, by discouraging the accumulation of financial capital, thus depriving the economic system of necessary lubrication in the form of adequate liquidity, and insufficient lubrication hampers economic efficiency and growth.

Even though inflation has been largely brought under control, macroeconomic management and organization remain problematic in Georgia. The interest-rate spread - that is, the interest rate charged by banks on loans to prime customers minus the interest rate paid by commercial or similar banks for demand, time, or savings deposits - is a simple measure of the efficiency of the banking system the commercial part of which, by the late 1990s, had in both countries been put into private hands. In Estonia foreigners own almost all banks assets compared with about two thirds in Georgia. In 2005, the interest spread was three percent in Estonia like in Finland in 2004, a respectable figure by international standards. In Georgia, on the other hand, the interest spread in 2005 was fourteen percent, suggesting continued inefficiency and lack of competition in the banking system, or high credit risks, despite full privatization (see Clark, Cull, and Shirley, 2004). Privatization and foreign ownership may not be enough, however, to increase competition and efficiency in the banking system. What matters most is the transfer of know-how, managerial experience, and fresh capital. Still, the Georgian figure of fourteen percent constitutes a significant improvement from earlier years when, from 2000 to 2004, the interest spread was between 20 percent and 24 percent even if inflation had been brought down to single digits (recall Figure 9).

Also, the Georgian economy remains heavily dependent on agriculture that still accounts for about a fifth of GDP as it did in the 1980s. By contrast, Estonia has little by little managed to diminish the share of its agriculture in GDP down to five percent which is only a little more than the EU average (Figure 11). This suggests both a stronger effort by the government to modernize the economy - by reducing farm support, for example - as well as greater mobility of labor and other factors of production between industries in Estonia than in Georgia. Accordingly, manufacturing and services have grown more rapidly in Estonia than in Georgia. During 1995-2005, manufacturing accounted for almost three fourths of Estonia's exports compared with about a third in Georgia (Figure 12). This matters because a strong manufacturing sector is ordinarily an important contributor to economic growth, partly because it is conducive to research and technological progress far beyond agriculture as well as to the buildup of human capital. Estonia's infrastructure is being modernized at a rapid 
pace. Electrical outages are rare: in 2005, electrical power was interrupted for one day compared with 39 days in Georgia. While, in 2006, it took 35 days to start a business in Estonia against 16 days in Georgia, more recent figures (World Bank, 2007) show that the time required to start a business in Estonia has fallen to a maximum of 7 days compared with 11 days in Georgia. Further, the cost of registering a business is much lower in Estonia than in Georgia, or five percent of GNI per capita in Estonia in 2006 against eleven percent in Georgia, down from 23 percent in 2003 (same source). The World Bank's Ease of Doing Business Index that ranks 178 countries by how conducive the regulatory environment is to business operation now puts Estonia in $17^{\text {th }}$ place and Georgia in $18^{\text {th }}$, up from $112^{\text {th }}$ place in 2003 , as mentioned before (see http://www.doingbusiness.org).

To give one more example, in Estonia, tax rates were cited as a major business constraint by three percent of the managers surveyed in 2005 compared with 36 percent in Georgia. These numbers suggest that different standards of governance may help explain why the transition from agriculture to manufacturing, trade, and services has been slower in Georgia than in Estonia.

To recapitulate, economic growth requires capital to be accumulated and to be efficiently used: real capital, human capital, foreign capital, and financial capital, all of which we have covered thus far, and also social capital to which we now turn.

\section{Democracy, Governance, and Demography}

Due to the difficult status of its Russian citizens, Estonia does not score as high in surveys of democracy as its neighbors, Latvia and Lithuania. According to political scientists at the University of Maryland (the Polity IV Project; see Marshall and Jaggers, 2001), Lithuania has scored a perfect ten since reclaiming its independence in 1991, Latvia eight, and Estonia six. For comparison, Georgia has scored between four and five since 1992 and, more recently, in 2004, seven (Figure 13). Democracy, we think, is good for growth because it improves governance. Democratization can be viewed as an investment in social capital by which we mean the infrastructural glue that holds society together and keeps it working harmoniously and well. Social capital comprises several other ingredients, including trust, the absence of rampant corruption, and reasonable equality in the distribution of income and wealth (see Paldam and Svendsen, 2000). The idea here is that political oppression, corruption, 
and excessive inequalities tend to diminish social cohesion and thereby also the quantity or quality of social capital.

According to the World Bank's Enterprise Surveys, about the same proportion of managers surveyed in 2005 said they lacked confidence in the court system to uphold property rights (30 percent in Estonia, 29 percent in Georgia). Even so, in Estonia, only two percent of the managers surveyed described their lack of confidence in the courts as a major business constraint compared with twelve percent in Georgia. In Estonia, two percent of the managers surveyed described crime as a major business constraint compared with 24 percent in Georgia. Further, according to Transparency International, there is a marked difference between Estonia and Georgia in terms of corruption. Figure 14 shows a three-to-four-point difference between the corruption perceptions indices for Estonia and Georgia. The World Bank reports a similar finding. In 2005, 20 percent of managers surveyed in Georgia described corruption as a major constraint on their business operations compared with four percent of managers in Estonia. Since 1999, Estonia has made some progress in the battle against corruption. However, Georgia has not, and remains one of the most corrupt countries in the region, and the world. This probably makes a difference because corruption is not good for growth (Mauro, 1995; see also Bardhan, 1997). Georgian managers say they have to spend three percent of their time dealing with officials compared with two percent in Estonia.

The distribution of income has become somewhat less unequal in Estonia than in Georgia; in 2003, the Gini index of inequality was 36 in Estonia and 40 in Georgia, whereas in the late 1990s it was 38 in both countries.

Figure 15 shows that both countries have suffered a collapse in fertility as measured by the number of live births per woman since 1987. Estonia has had a partial recovery since 1996, but Georgia has not. The population of both countries continues to decline. Even if excessive fertility holds back economic growth in many developing countries, population decline is not likely to increase per capita growth in Estonia and Georgia, on the contrary. Life expectancy at birth took a deep dive in Estonia before 1990, did not recover until a decade later, and then sailed past that of Georgia in the late 1990s (Figure 16). Public and private health expenditures in Estonia have exceeded those in Georgia in recent years, but the gap between the two countries has narrowed. In 2001, Estonia had 6.7 hospital beds per 1,000 inhabitants compared with 4.3 in Georgia. In recent years, all child births in Estonia have been 
attended by skilled medical staff compared with 92 percent in Georgia. Public health and fertility are closely related to human capital and hence important to economic growth over time.

\section{Conclusion}

Our comparison of the different development trajectories of Estonia and Georgia since 1991 suggests policy implications that seem especially relevant to Georgia and other second-tier FSU states as well as to other countries elsewhere that have lagged behind their erstwhile equals (recall Figure 1). In brief, rapid economic growth requires

(i) Public policies that support education and training, free trade, and domestic as well as foreign investment in a business-friendly environment.

(ii) Monetary and fiscal policies that support price stability and sound private banking and other financial intermediation, sustainable government budget positions, and international, consumer-friendly competition.

(iii) Sound and transparent societal institutions that support the rule of law.

(iv) Good governance of both the public sector and the private sector.

By and large, it seems that on all counts Estonia, up to now, has surpassed Georgia. While recent developments and data suggest that Georgia, at last, has begun to catch up, doubts remain regarding the country's institutional reform agenda as well as the still unresolved territorial disputes.

Referring back to the classification of the main determinants of economic efficiency and growth implied by the aggregate production function presented in Section 2, we can now summarize our findings as follows.

First, Estonia has invested significantly more relative to GDP than Georgia and also attracted more foreign investment than Georgia, thereby accumulating capital and increasing output per person. Increased high-quality investment contributes to more rapid growth over long periods, other things being the same.

In second place, Estonia sends more young people to secondary schools as well as to colleges and universities than Georgia does, thereby building up precious human capital that, like real capital accumulation, helps lift output per person to higher levels and encourage long-term growth. Estonia's strong emphasis on education at all levels is reinforced by its rapidly increasing technological sophistication as evidenced by 
widespread personal computer and mobile phone ownership.

Third, Estonia has done more than Georgia to increase economic efficiency - that is, total factor productivity. This effort has taken many different forms. Let us start with the important trinity of liberalization, privatization, and stabilization. Estonia has managed to

(i) Increase its openness to trade in goods, services, and capital,

(ii) Privatize its banks and other erstwhile state enterprises while ensuring competition through, among other things, foreign ownership, and

(iii) Stabilize prices following the temporary bout of inflation that was bound to follow the rapid liberalization of prices at the beginning of transition.

Georgia has not managed to liberalize trade to the same extent, nor has Georgia managed to privatize its banks and other state-owned enterprises while ensuring strong competition. On the other hand, Georgia has successfully stabilized prices, albeit a bit less rapidly than Estonia. On top of all this, according to almost all the different governance indicators that we compared for the two countries, Estonia has moved farther and faster in a growth-friendly direction. Most notably, corruption and associated problems are much less of an issue in Estonia than in Georgia.

In view of all this, we are not surprised that Estonia has grown more rapidly than Georgia, despite Georgia’s advantage of starting from a much lower level of initial income after the plunge following independence. Our story suggests that the growth differential between the two countries since 1993 would probably have been significantly larger than half a percentage point - that is, the difference between Estonia’s 6.6 percent growth per year and Georgia’s 6.1 percent - had both countries started out in the same initial position. The proportions in which these many different factors account for the growth differential between the two countries since 1991 remain to be quantified. Even so, we think the qualitative point we have made is pretty clear. You judge. 


\section{References}

Acemoglu, Daron, Simon Johnson, and James Robinson (2002), "Reversal of Fortune: Geography and Development in the Making of the Modern World Income Distribution," Quarterly Journal of Economics, Vol. 117, No. 4, November, 12311294.

Acemoglu, Daron, and Simon Johnson (2005), “Unbundling Institutions,” Journal of Political Economy, Vol. 113, No. 5, October, 949-995.

Bardhan, Pranab (1997), "Corruption and Development: A Review of the Issues," Journal of Economic Literature, Vol. 35, No. 3, September, 1320-1346.

Clarke, George R. G., Robert Cull, and Mary Shirley, "Empirical Studies of Bank Privatization: Some Lessons,” paper presented at the $8^{\text {th }}$ Annual Conference of the International Society for New Institutional Economics in Tucson, Arizona, 30 September - 3 October, 2004.

Dixit, Avinash (2004), Lawlessness and Economics: Alternative Institutions of Governance (Princeton: Princeton University Press), Chapter 1. Available at http://pup.princeton.edu/titles/7729.html.

Hall, Robert E., and Charles I. Jones (1999), "Why Do Some Countries Produce So Much More Output Per Worker Than Others?,” Quarterly Journal of Economics, Vol. 114, No. 1, February, 83-116.

Marshall, Monty G., and Keith Jaggers (2001), "Polity IV Project: Political Regime Characteristics and Transitions, 1800-2000.” Available at http://www.cidcm.umd.edu./inscr/polity/.

Marsiliani, Laura, and Thomas, I. Renström (2007), "Political Institutions and Economic Growth,” Economics of Governance, Vol. 8, No. 3, May, 233-261.

Mauro, Paolo (1995), “Corruption and Growth,” Quarterly Journal of Economics, Vol. 110, No. 3, August, 681-712.

Paldam, Martin, and Gert Tinggaard Svendsen (2000), “An Essay on Social Capital: Looking at the Fire behind the Smoke," European Journal of Political Economy Vol. 16, No. 2, June, 339-366.

Sachs, Jeffrey D., and Andrew M. Warner (1995, revised 1997, 1999), "Natural Resource Abundance and Economic Growth,” NBER Working Paper 5398, Cambridge, Massachusetts. 
Williamson, Oliver, 2005, “The Economics of Governance,” American Economic Review, Vol. 95, No. 2, May, 1-18.

World Bank (2007), Doing Business - Economy Rankings. Available at http://www.doingbusiness.org. See also http://www.enterprisesurveys.org. 
Figure 1. Gross National Income per capita 1991 and 2006

(International dollars at purchasing power parity)

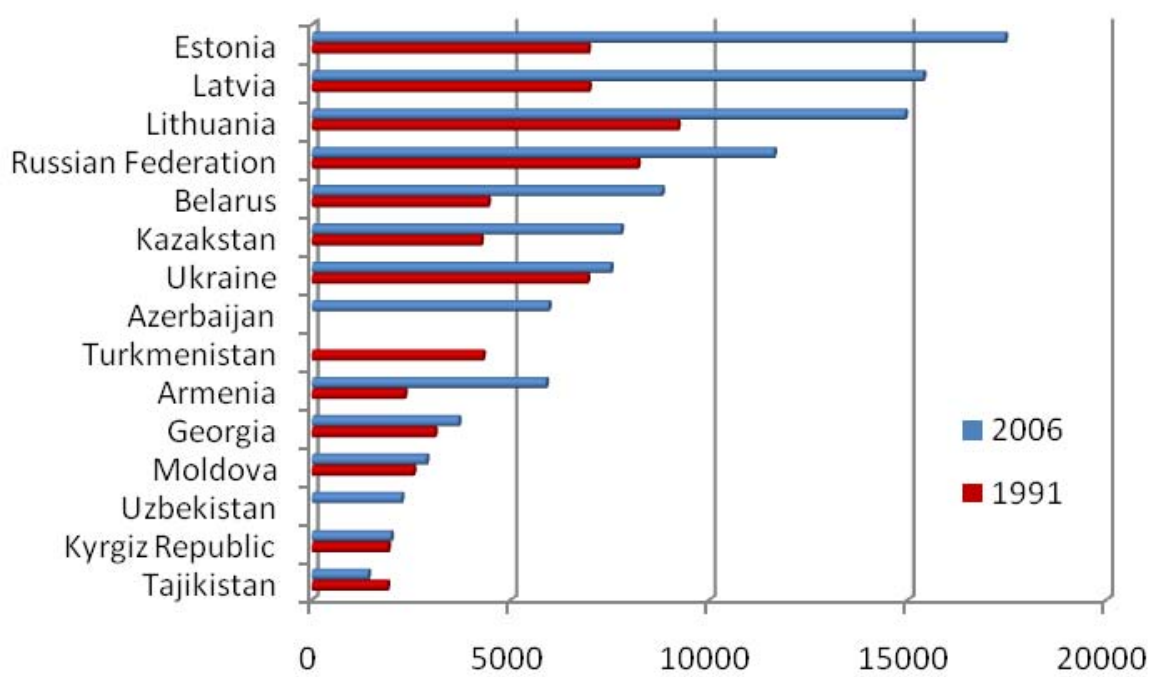

Note: Data for Turkmenistan 2006 and Azerbaijan and Uzbekistan 1991 are not available. Source: World Bank, World Development Indicators 2007.

Figure 2. Gross Domestic Product per capita 1975-2005

(Constant 2000 international dollars at purchasing power parity)

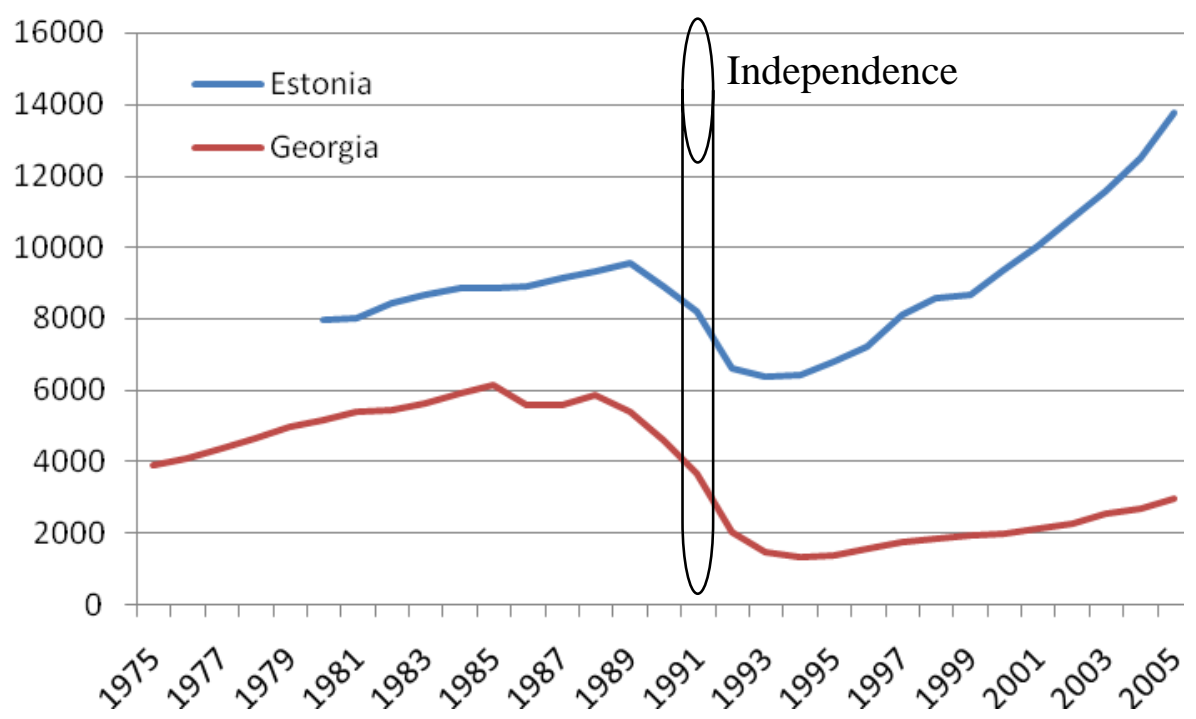

Source: World Bank, World Development Indicators 2007. 
Figure 3. Gross Domestic Product per capita 1975-2005

(Constant 2000 international dollars at purchasing power parity, logarithmic scale)

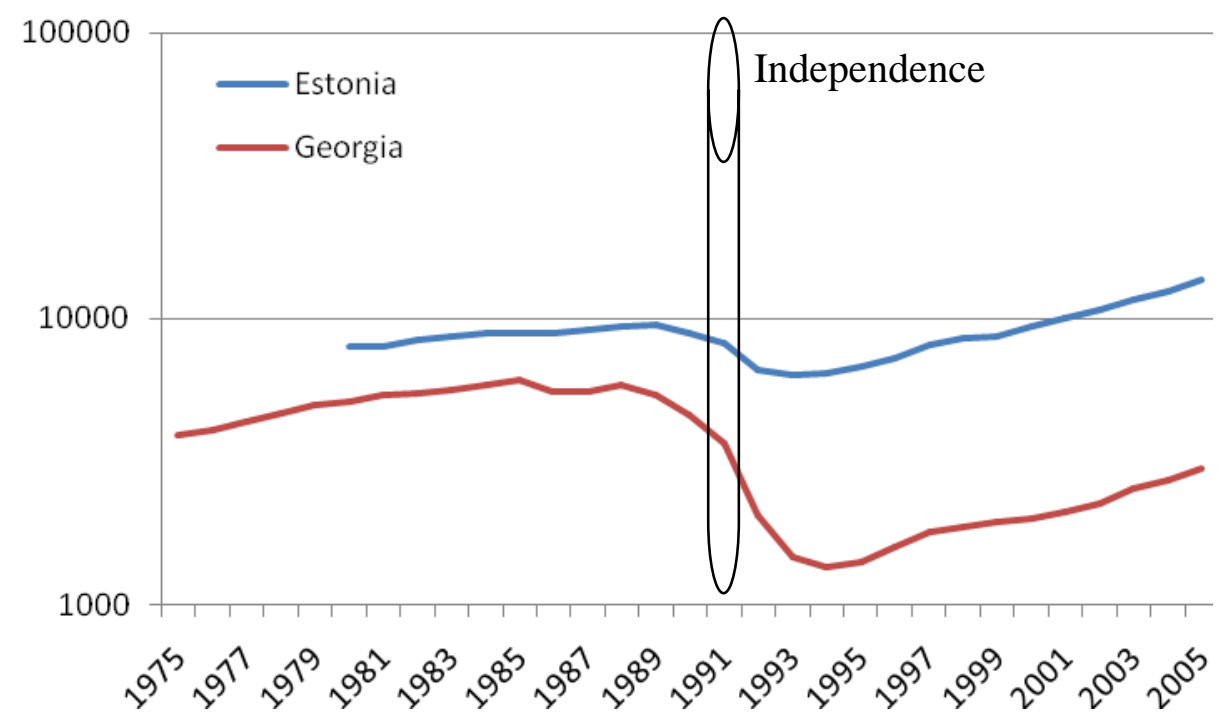

Source: World Bank, World Development Indicators 2007.

Figure 4. Gross Capital Formation 1980-2005 (\% of GDP)

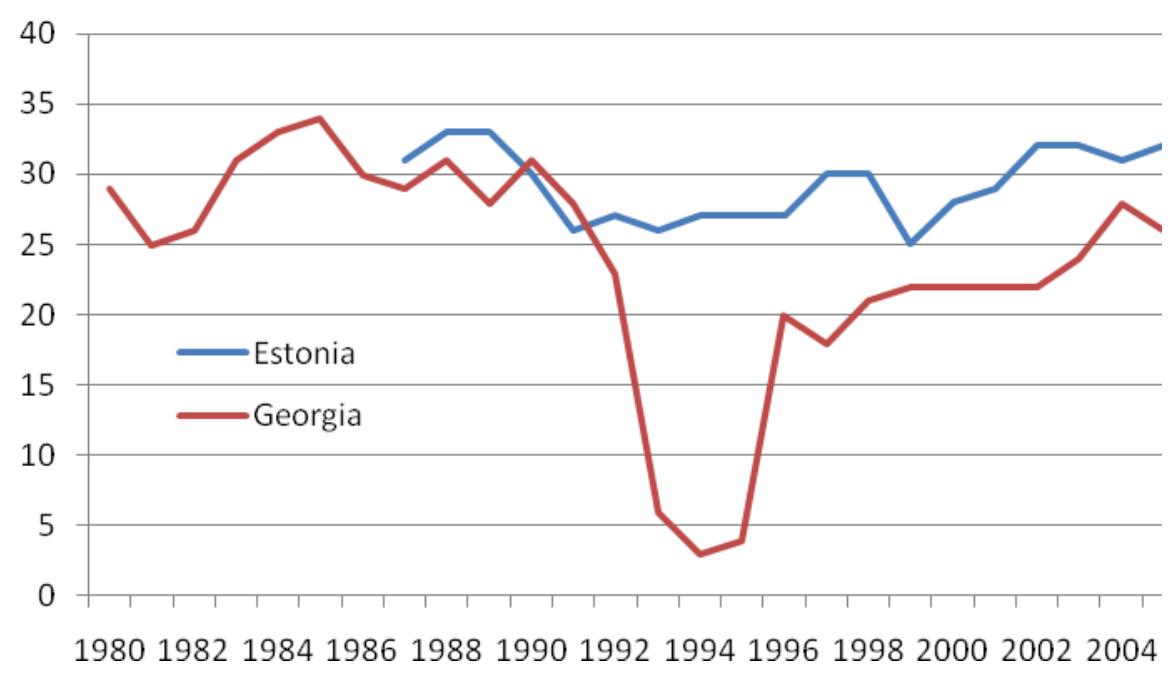

Source: World Bank, World Development Indicators 2007. 
Figure 5. Secondary-School Enrolment 1991-2005 (\% of Cohort)

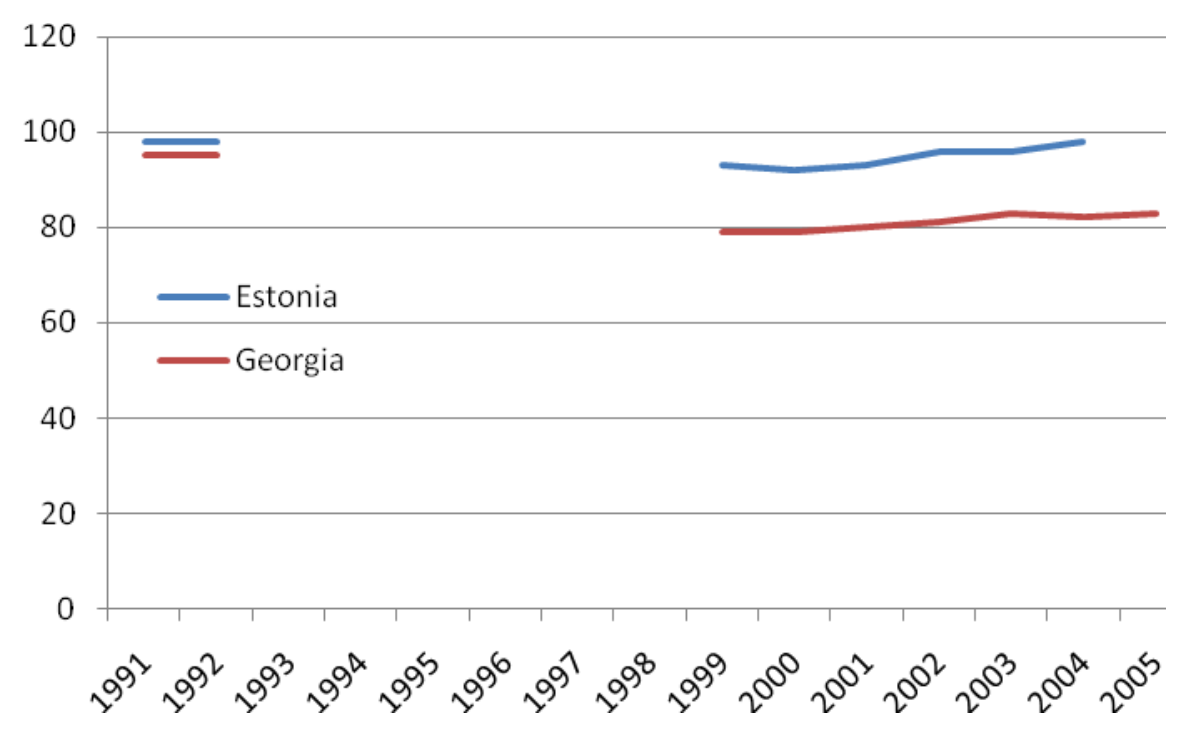

Source: World Bank, World Development Indicators 2007.

Figure 6. Foreign Direct Investment 1992-2005 (Net Inflows, \% of GDP)

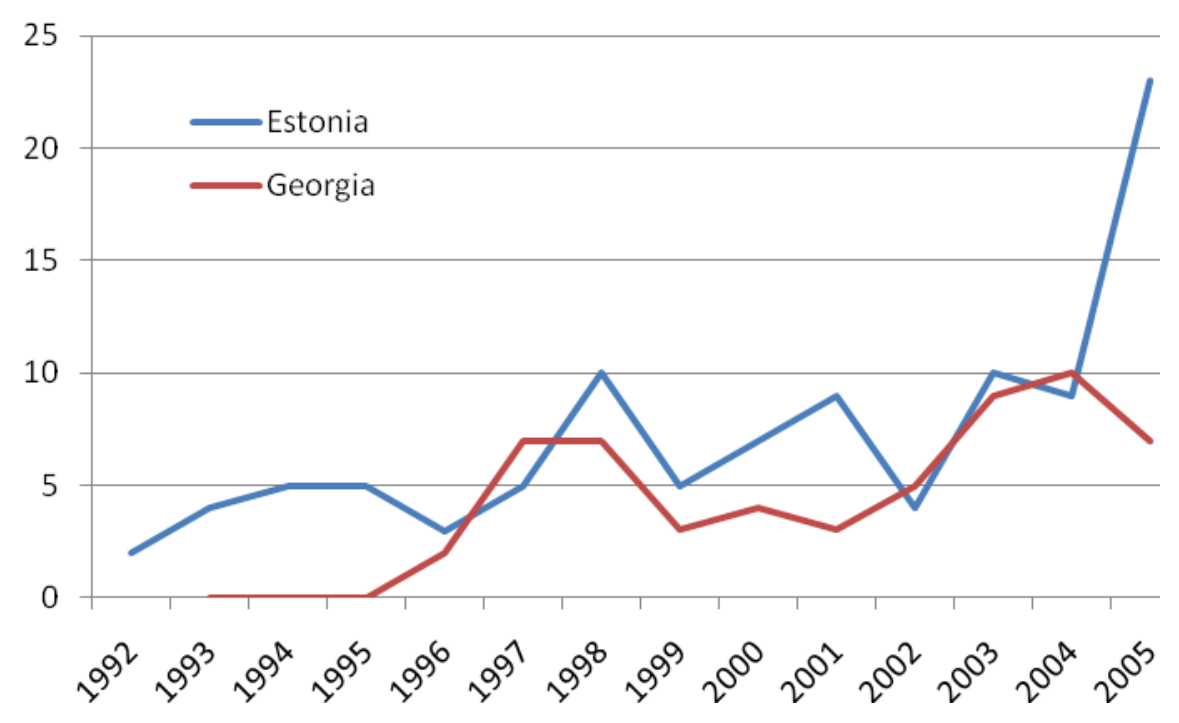

Source: World Bank, World Development Indicators 2007. 
Figure 7. Exports of Goods and Services 1987-2005 (\% of GDP)

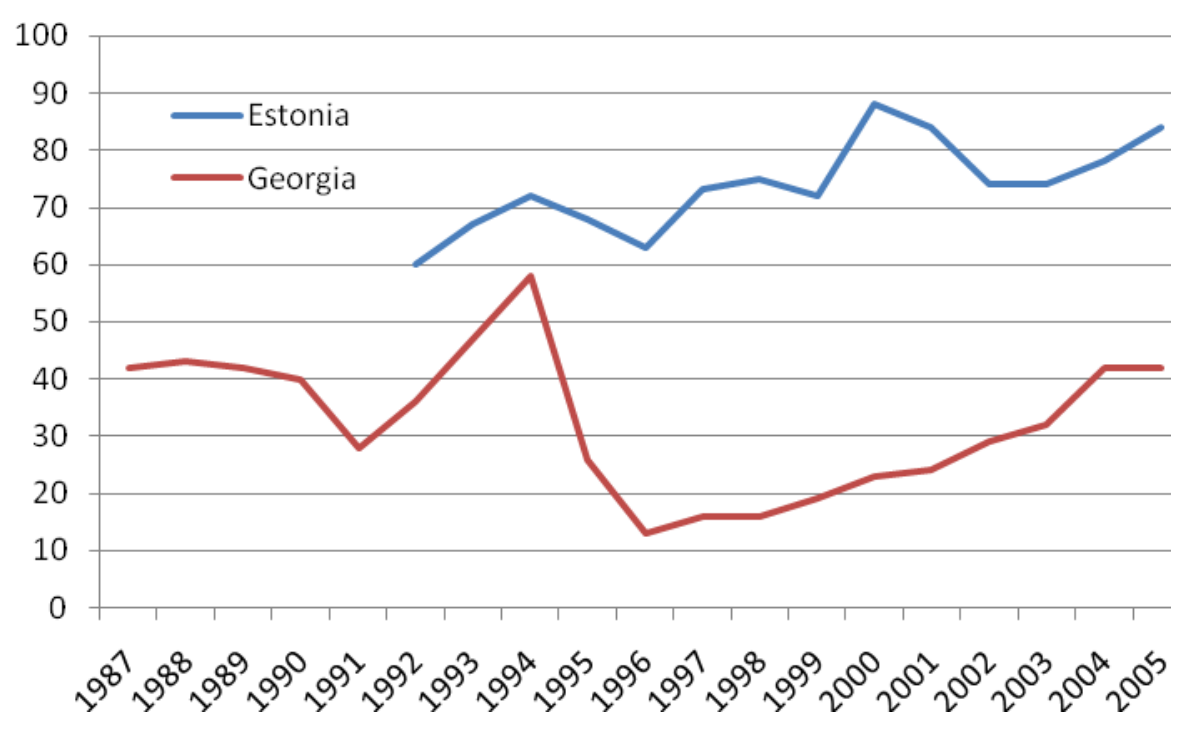

Source: World Bank, World Development Indicators 2007.

Figure 8. Customs and Other Import Duties 1991-2005 (\% of Tax Revenue)

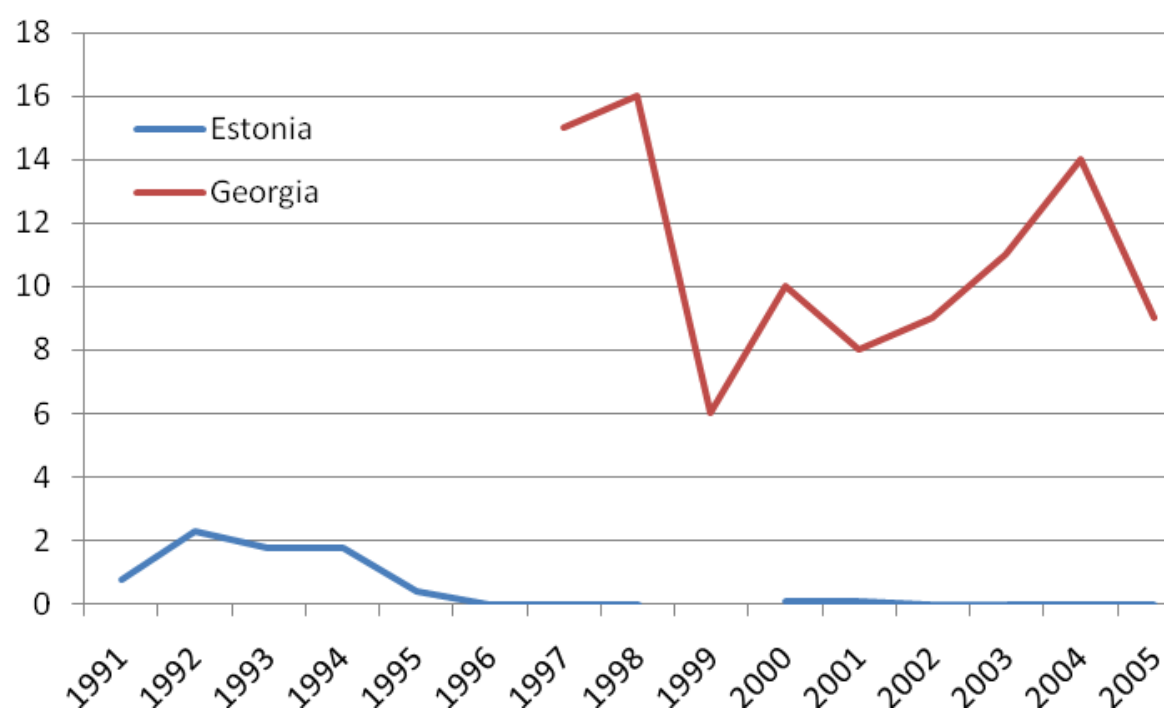

Source: World Bank, World Development Indicators 2005 and 2007. 
Figure 9. Inflation 1993-2005 (\%, Consumer Prices)

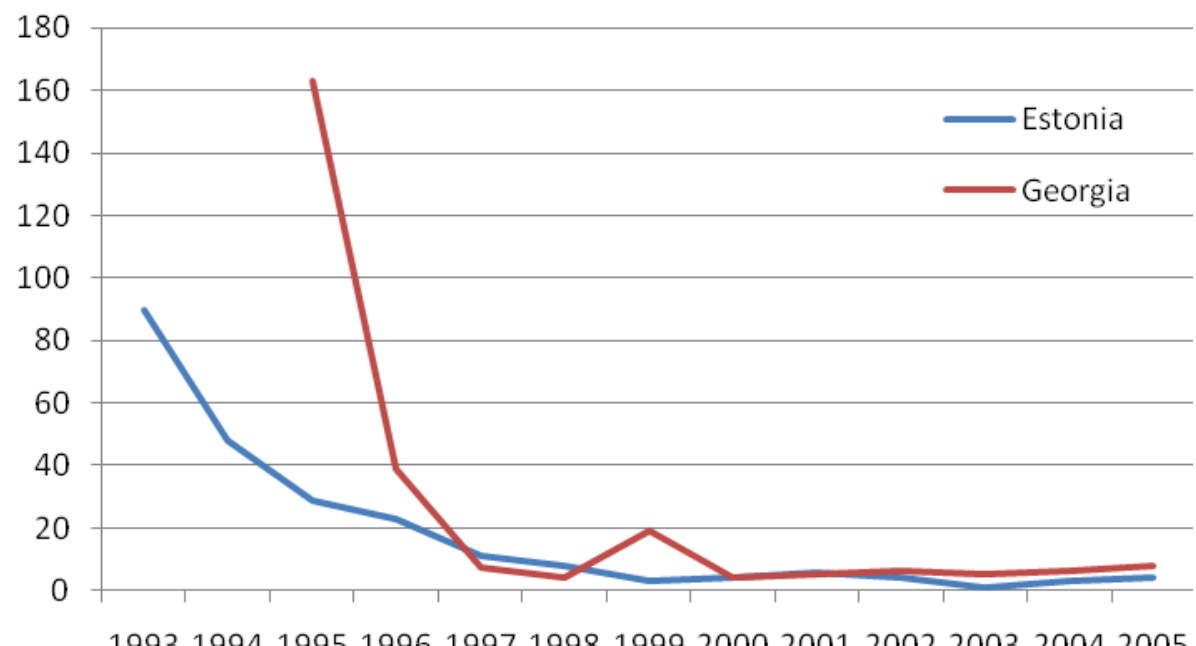

Source: World Bank, World Development Indicators 2007.

Figure 10. Financial Depth 1992-2005 (Broad Money as \% of GDP)

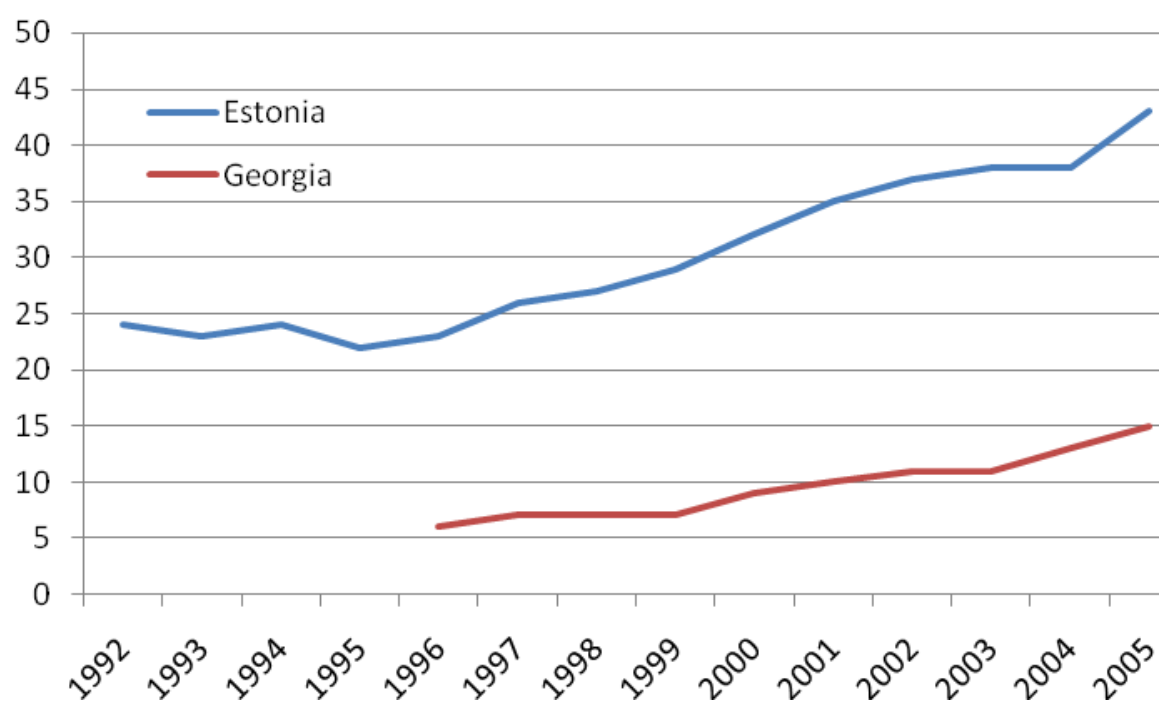

Source: World Bank, World Development Indicators 2007. 
Figure 11. Agriculture 1980-2005 (Value Added as \% of GDP)

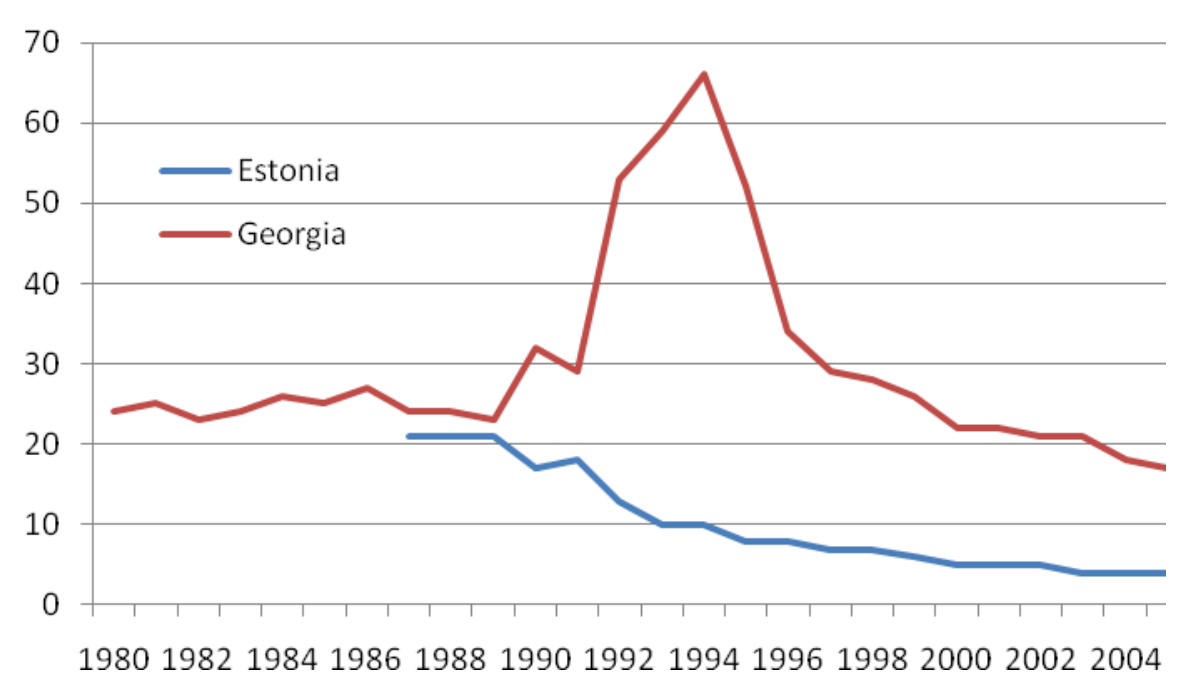

Source: World Bank, World Development Indicators 2007.

Figure 12. Manufactures Exports 1995-2005 (\% of Merchandise Exports)

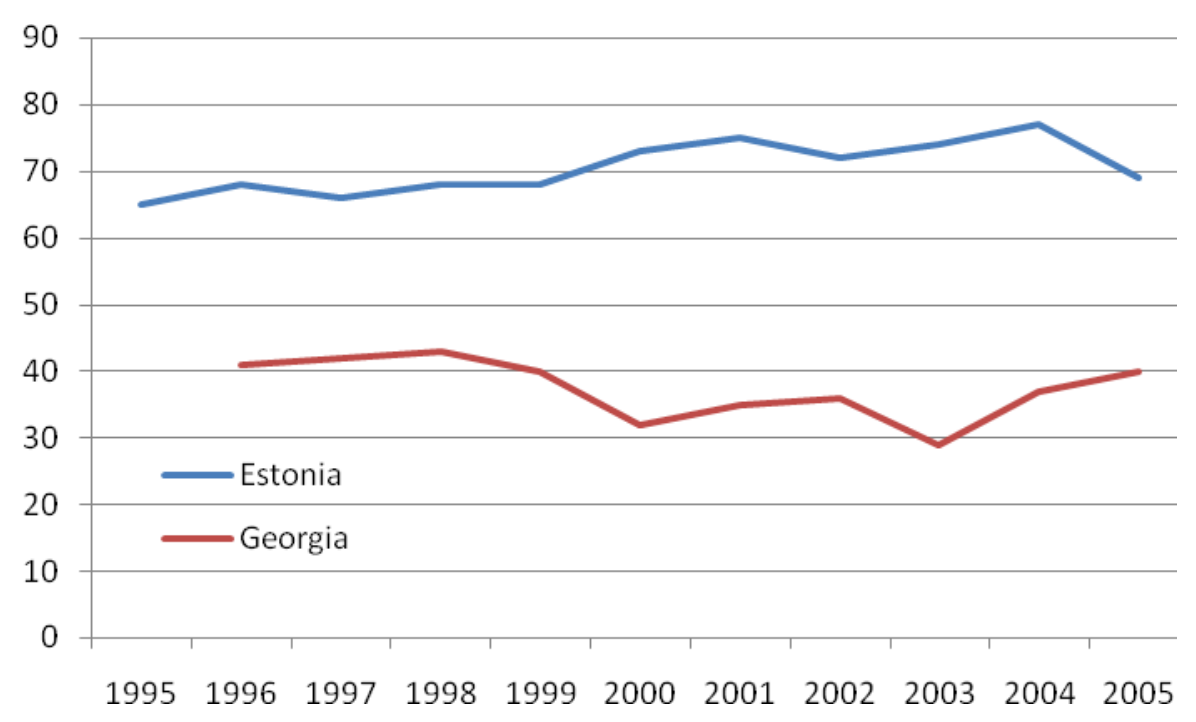

Source: World Bank, World Development Indicators 2007. 
Figure 13. Democracy 1991-2004 (Index from -10 to 10)

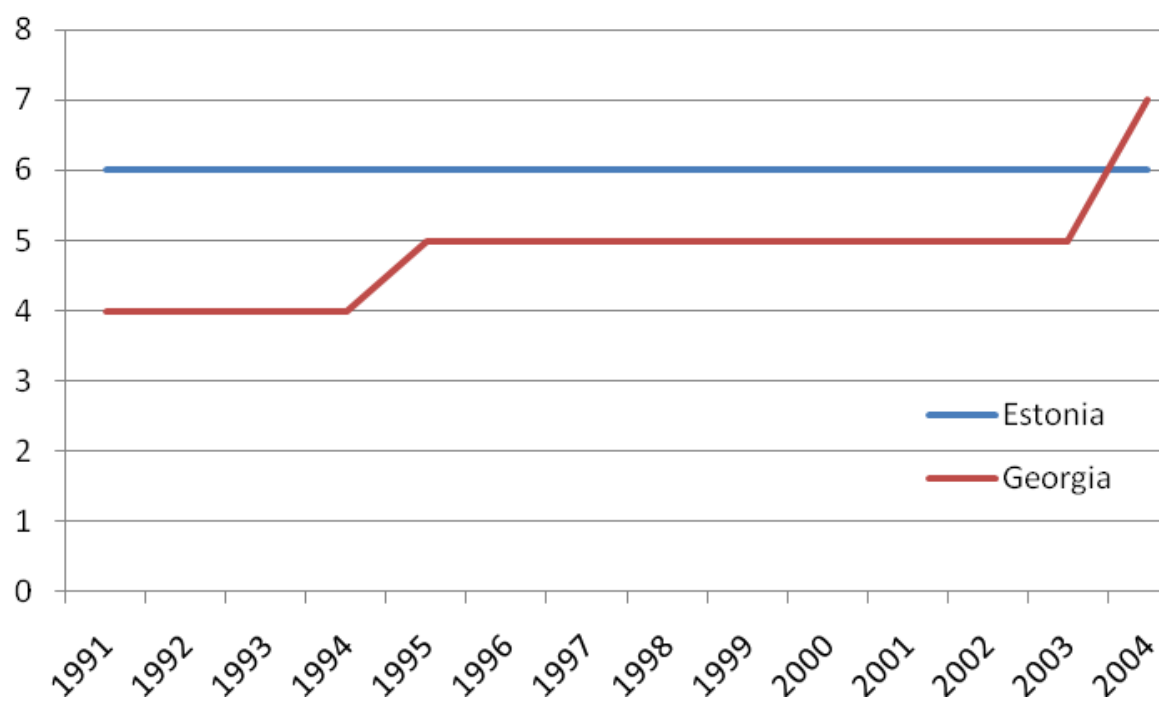

Source: World Bank, World Development Indicators 2007.

Figure 14. Corruption 1998-2006 (Index from 1 to 10)

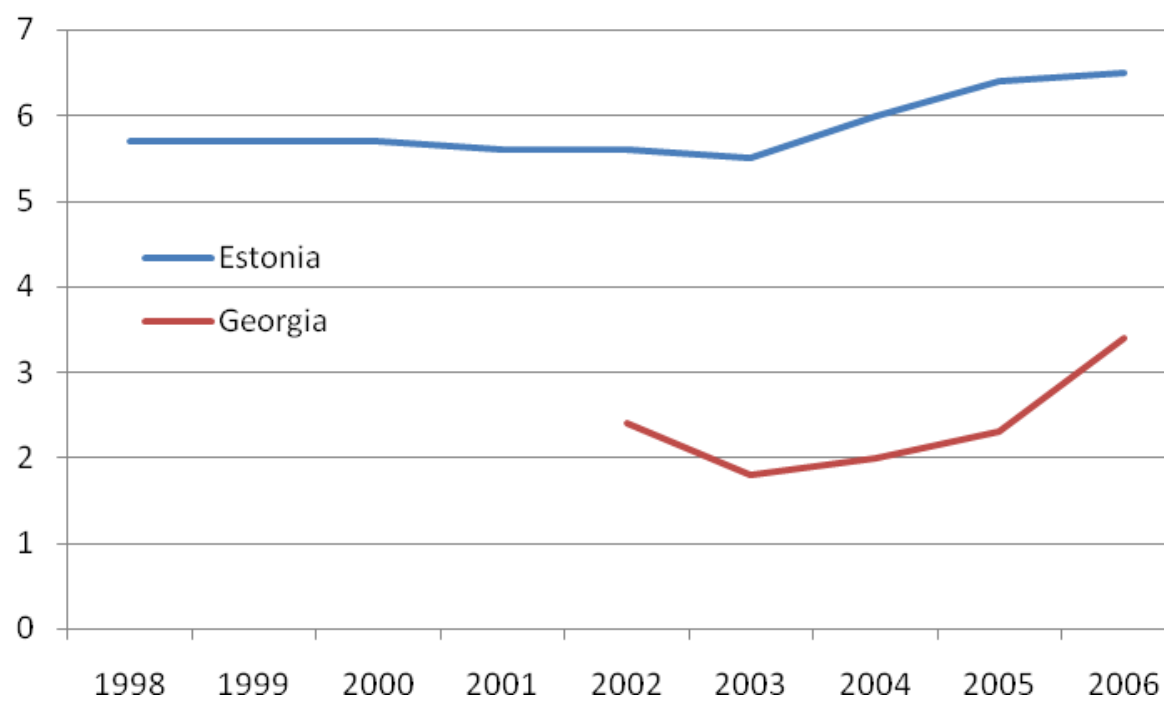

Source: Transparency International, 1999-2007. 
Figure 15. Fertility 1960-2005 (Live Births per Woman)

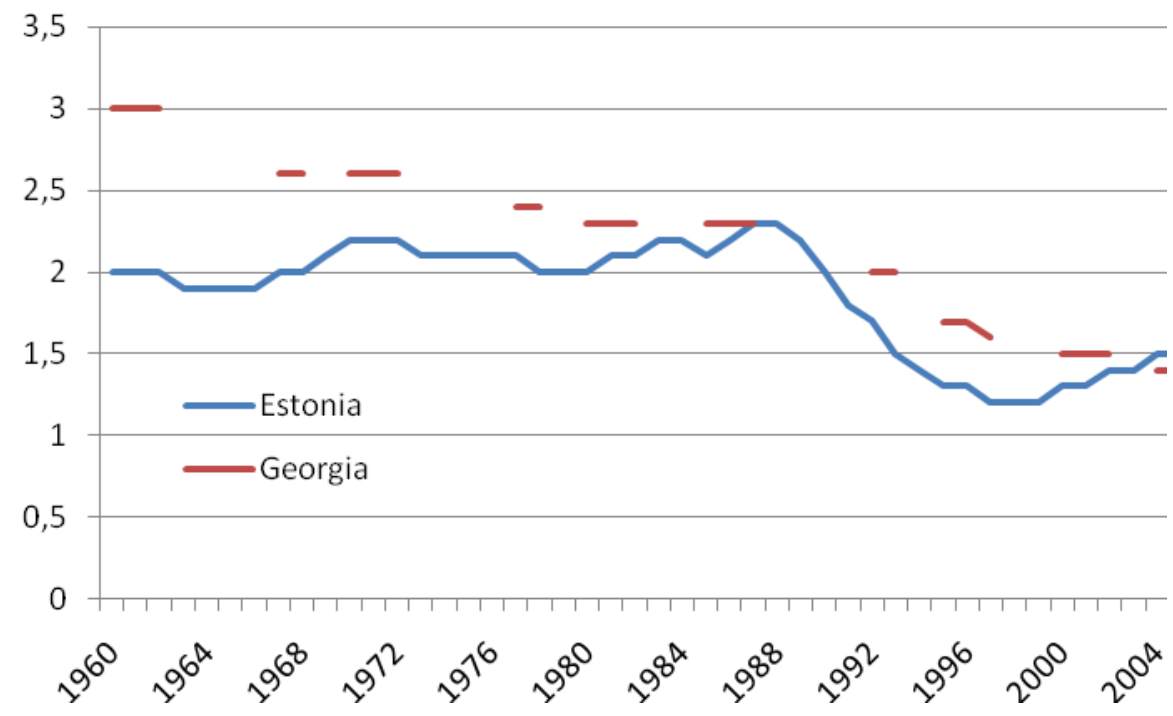

Source: World Bank, World Development Indicators 2007.

Figure 16. Life Expectancy at Birth 1960-2005 (Years)

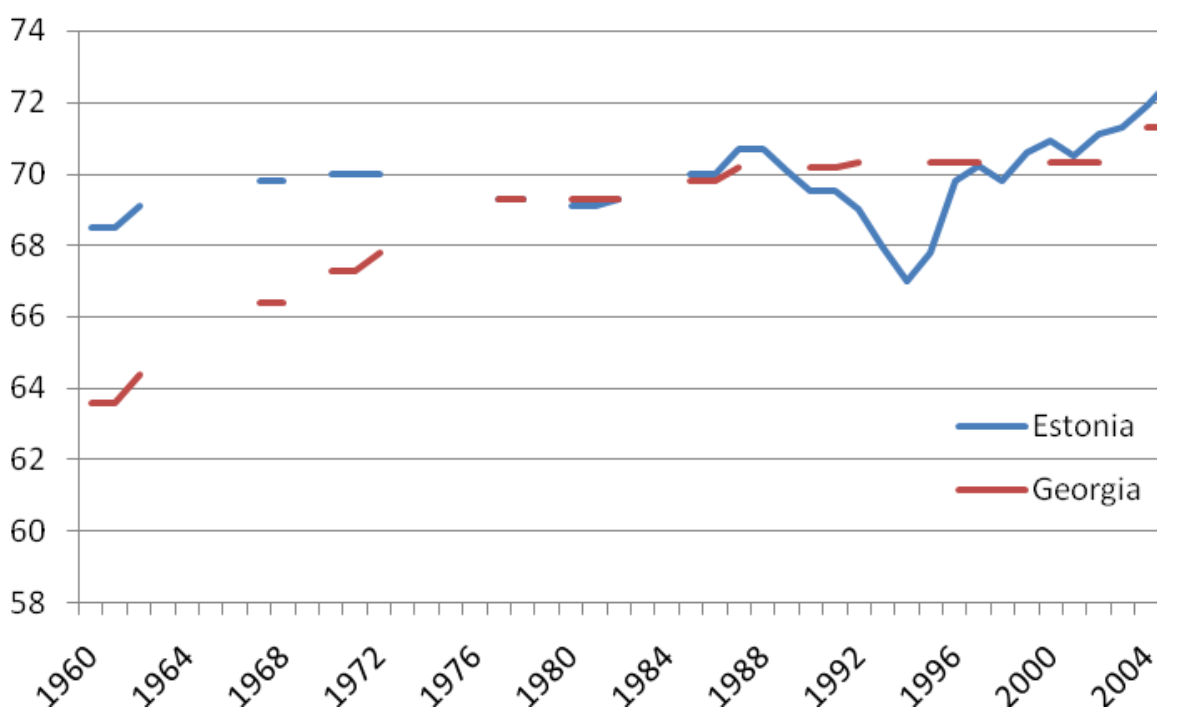

Source: World Bank, World Development Indicators 2007. 


\section{CESifo Working Paper Series}

for full list see www.cesifo-group.org/wp

(address: Poschingerstr. 5, 81679 Munich, Germany, office@cesifo.de)

2092 Henrik Jacobsen Kleven, Claus Thustrup Kreiner and Emmanuel Saez, The Optimal Income Taxation of Couples as a Multi-Dimensional Screening Problem, September 2007

2093 Michael Rauber and Heinrich W. Ursprung, Life Cycle and Cohort Productivity in Economic Research: The Case of Germany, September 2007

2094 David B. Audretsch, Oliver Falck and Stephan Heblich, It's All in Marshall: The Impact of External Economies on Regional Dynamics, September 2007

2095 Michael Binder and Christian J. Offermanns, International Investment Positions and Exchange Rate Dynamics: A Dynamic Panel Analysis, September 2007

2096 Louis N. Christofides and Amy Chen Peng, Real Wage Chronologies, September 2007

2097 Martin Kolmar and Andreas Wagener, Tax Competition with Formula Apportionment: The Interaction between Tax Base and Sharing Mechanism, September 2007

2098 Daniela Treutlein, What actually Happens to EU Directives in the Member States? - A Cross-Country Cross-Sector View on National Transposition Instruments, September 2007

2099 Emmanuel C. Mamatzakis, An Analysis of the Impact of Public Infrastructure on Productivity Performance of Mexican Industry, September 2007

2100 Gunther Schnabl and Andreas Hoffmann, Monetary Policy, Vagabonding Liquidity and Bursting Bubbles in New and Emerging Markets - An Overinvestment View, September 2007

2101 Panu Poutvaara, The Expansion of Higher Education and Time-Consistent Taxation, September 2007

2102 Marko Koethenbuerger and Ben Lockwood, Does Tax Competition Really Promote Growth?, September 2007

2103 M. Hashem Pesaran and Elisa Tosetti, Large Panels with Common Factors and Spatial Correlations, September 2007

2104 Laszlo Goerke and Marco Runkel, Tax Evasion and Competition, September 2007

2105 Scott Alan Carson, Slave Prices, Geography and Insolation in $19^{\text {th }}$ Century AfricanAmerican Stature, September 2007

2106 Wolfram F. Richter, Efficient Tax Policy Ranks Education Higher than Saving, October 2007 
2107 Jarko Fidrmuc and Roman Horváth, Volatility of Exchange Rates in Selected New EU Members: Evidence from Daily Data, October 2007

2108 Torben M. Andersen and Michael Svarer, Flexicurity - Labour Market Performance in Denmark, October 2007

2109 Jonathan P. Thomas and Tim Worrall, Limited Commitment Models of the Labor Market, October 2007

2110 Carlos Pestana Barros, Guglielmo Maria Caporale and Luis A. Gil-Alana, Identification of Segments of European Banks with a Latent Class Frontier Model, October 2007

2111 Felicitas Nowak-Lehmann D., Sebastian Vollmer and Immaculada Martínez-Zarzoso, Competitiveness - A Comparison of China and Mexico, October 2007

2112 Mark Mink, Jan P.A.M. Jacobs and Jakob de Haan, Measuring Synchronicity and Comovement of Business Cycles with an Application to the Euro Area, October 2007

2113 Ossip Hühnerbein and Tobias Seidel, Intra-regional Tax Competition and Economic Geography, October 2007

2114 Christian Keuschnigg, Exports, Foreign Direct Investment and the Costs of Corporate Taxation, October 2007

2115 Werner Bönte, Oliver Falck and Stephan Heblich, Demography and Innovative Entrepreneurship, October 2007

2116 Katrin Assenmacher-Wesche and M. Hashem Pesaran, Assessing Forecast Uncertainties in a VECX Model for Switzerland: An Exercise in Forecast Combination across Models and Observation Windows, October 2007

2117 Ben Lockwood, Voting, Lobbying, and the Decentralization Theorem, October 2007

2118 Andrea Ichino, Guido Schwerdt, Rudolf Winter-Ebmer and Josef Zweimüller, Too Old to Work, too Young to Retire?, October 2007

2119 Wolfgang Eggert, Tim Krieger and Volker Meier, Education, Unemployment and Migration, October 2007

2120 Stefan Napel and Mika Widgrén, The European Commission - Appointment, Preferences, and Institutional Relations, October 2007

2121 Bertil Holmlund and Martin Söderström, Estimating Income Responses to Tax Changes: A Dynamic Panel Data Approach, October 2007

2122 Doina Maria Radulescu, From Separate Accounting to Formula Apportionment: Analysis in a Dynamic Framework, October 2007

2123 Jelle Brouwer, Richard Paap and Jean-Marie Viaene, The Trade and FDI Effects of EMU Enlargement, October 2007 
2124 Kurt R. Brekke, Luigi Siciliani and Odd Rune Straume, Competition and Waiting Times in Hospital Markets, October 2007

2125 Alexis Direr, Flexible Life Annuities, October 2007

2126 Johannes Becker and Clemens Fuest, Quality versus Quantity - The Composition Effect of Corporate Taxation on Foreign Direct Investment, October 2007

2127 Balázs Égert, Real Convergence, Price Level Convergence and Inflation Differentials in Europe, October 2007

2128 Marko Koethenbuerger, Revisiting the "Decentralization Theorem" - On the Role of Externalities, October 2007

2129 Axel Dreher, Silvia Marchesi and James Raymond Vreeland, The Politics of IMF Forecasts, October 2007

2130 Andreas Knabe and Ronnie Schöb, Subsidizing Extra Jobs: Promoting Employment by Taming the Unions, October 2007

2131 Michel Beine and Bertrand Candelon, Liberalization and Stock Market Co-Movement between Emerging Economies, October 2007

2132 Dieter M. Urban, FDI Technology Spillovers and Wages, October 2007

2133 Valentina Bosetti, Carlo Carraro, Emanuele Massetti and Massimo Tavoni, Optimal Energy Investment and R\&D Strategies to Stabilise Greenhouse Gas Atmospheric Concentrations, October 2007

2134 David-Jan Jansen and Jakob de Haan, The Importance of Being Vigilant: Has ECB Communication Influenced Euro Area Inflation Expectations?, October 2007

2135 Oliver Falck, Heavyweights - The Impact of Large Businesses on Productivity Growth, October 2007

2136 Xavier Freixas and Bruno M. Parigi, Banking Regulation and Prompt Corrective Action, November 2007

2137 Jan K. Brueckner, Partial Fiscal Decentralization, November 2007

2138 Silvia Console Battilana, Uncovered Power: External Agenda Setting, Sophisticated Voting, and Transnational Lobbying, November 2007

2139 Alan J. Auerbach, Michael P. Devereux and Helen Simpson, Taxing Corporate Income, November 2007

2140 Lorenzo Cappellari, Paolo Ghinetti and Gilberto Turati, On Time and Money Donations, November 2007 
2141 Roel Beetsma and Heikki Oksanen, Pension Systems, Ageing and the Stability and Growth Pact, November 2007

2142 Hikaru Ogawa and David E. Wildasin, Think Locally, Act Locally: Spillovers, Spillbacks, and Efficient Decentralized Policymaking, November 2007

2143 Alessandro Cigno, A Theoretical Analysis of the Effects of Legislation on Marriage, Fertility, Domestic Division of Labour, and the Education of Children, November 2007

2144 Kai A. Konrad, Mobile Tax Base as a Global Common, November 2007

2145 Ola Kvaløy and Trond E. Olsen, The Rise of Individual Performance Pay, November 2007

2146 Guglielmo Maria Caporale, Yannis Georgellis, Nicholas Tsitsianis and Ya Ping Yin, Income and Happiness across Europe: Do Reference Values Matter?, November 2007

2147 Dan Anderberg, Tax Credits, Income Support and Partnership Decisions, November 2007

2148 Andreas Irmen and Rainer Klump, Factor Substitution, Income Distribution, and Growth in a Generalized Neoclassical Model, November 2007

2149 Lorenz Blume, Jens Müller and Stefan Voigt, The Economic Effects of Direct Democracy - A First Global Assessment, November 2007

2150 Axel Dreher, Pierre-Guillaume Méon and Friedrich Schneider, The Devil is in the Shadow - Do Institutions Affect Income and Productivity or only Official Income and Official Productivity?, November 2007

2151 Valentina Bosetti, Carlo Carraro, Emanuele Massetti and Massimo Tavoni, International Energy R\&D Spillovers and the Economics of Greenhouse Gas Atmospheric Stabilization, November 2007

2152 Balázs Égert and Dubravko Mihaljek, Determinants of House Prices in Central and Eastern Europe, November 2007

2153 Christa Hainz and Hendrik Hakenes, The Politician and his Banker, November 2007

2154 Josef Falkinger, Distribution and Use of Knowledge under the "Laws of the Web", December 2007

2155 Thorvaldur Gylfason and Eduard Hochreiter, Growing Apart? A Tale of Two Republics: Estonia and Georgia, December 2007 